\title{
TARTU KOOLINOORTE VASTUPANU VENESTAMISPOLIITIKALE XX SAJANDI ALGUSES
}

\author{
LJUBOV KISSELJOVA
}

$\mathrm{T}$ artus Vanemuise seltsis toimus 17. jaanuaril 1903 kirjandusõhtu Mihkel Veske (1843-1890) 60. sünniaastapäeva puhul. Õhtu kuulus rahvuslike ettevõtmiste hulka, mis tähistasid eesti kultuuri olulisi tähtpäevi. Juba varem, 11. detsembril 1902 toimusid nii Karskuse Sõbras kui ka Taara seltsis Lydia Koidula mälestusõhtud. Need sündmused äratasid ühiskonnas suurt vastukaja ja tekitasid samal ajal ka võimude rahulolematust: viimased nägid neis sündmustes (ja mitte põhjuseta) protesti väikerahvaste kultuuri alla suruva tsaaririigi poliitika vastu.

Kõigepealt äratas kahtlust Veskele pühendatud õhtu. Kuidas oli võimalik seostada vastuseisuga tsaaririigi poliitikale luuletajat ja keeleteadlast, eesti rahvusliku liikumise esimesse põlvkonda kuulunud Vesket, kes oli kindlalt veendunud, et võitlust saksa mõisnike rõhumise vastu ja tegevust oma kultuuri arendamisel saab toetada ainult Vene keiser ja tema valitsus? Mälestusõhtul kõlas Veske ülimalt lojaalne luuletus „Isa sõnad”, milles kiideti pärisorjuse kaotamist - vabadust, mille oli eesti rahvale kinkinud keiser Aleksander I.

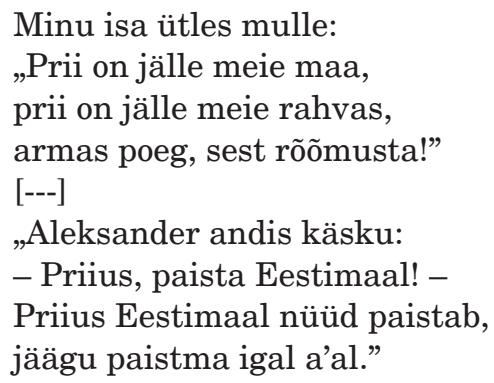

Selle kirjandusõhtuga seotud uurimine kestis mitu kuud. Ühena esimestest lõi häirekella 3. politseijaoskonna ülem, kes 2. märtsil 1903 kirjutas Tartu politseimeistrile salajase raporti, mille on 1968. aastal avaldanud Sergei Issakov (1968). Nagu tuleb välja raporti tekstist, sai ülem ise informatsiooni hilinemisega kolmandatelt isikutelt. Kaebus oli sealjuures põhjalik, ära oli toodud Veske õhtu programm ning korraldajate ja osalejate nimekiri. Politseimeister saatis kaebuse edasi Riiga Liivimaa kubernerile. Kuid peatselt, 16. märtsil saabus uus kaebus samalt isikult - nüüd juba hoopis varem toimunud sündmuste, nimelt Koidula mälestusõhtute kohta (Issakov 1968: 622-623). Seegi kaebus saadeti otsekohe kubernerile ja algas intensiivne kirjavahetus. 
Issakov avaldas need dokumendid, kuid ei arendanud teemat edasi. Rahvusarhiivis asuvas Tartu linna politseivalitsuse kantselei arhiivi fondis on ka „Seltside toimik” (Дело об обществах 1903-1904), kus säilitatakse kirjavahetust Tartu ja Riia vahel (RA, EAA.325.1.490). Üks osa sellest kirjavahetusest asub Riias, seda ei ole ma kasutanud. Kirjavahetusest tuleb ilmsiks Liivimaa kuberneri Mihhail Paškovi rahulolematus, tema katsed välja selgitada ettevõtmiste võimalik ohtlikkus ja vastavalt sellele karistada korraldajaid. Peatselt järgnesidki repressioonid. Tundub, et politseisse saadetud kaebuste taga olid mõned haridusametnikud. Kahe silmapaistva eesti kultuuritegelase mälestusõhtud olid omamoodi julge ja mitmetähenduslik žest, mis kõneles rahvuslikkuse tõusu uuest etapist.

Sellest ilmekast ja väga olulisest XX sajandi alguse Tartu ajaloo episoodist on kirjutanud Friedebert Tuglas oma mälestustes "Tartu linnakoolis" (Tuglas 1940a), ${ }^{1}$ mis on avaldatud ka „Noorusmälestustes” (Tuglas 1940b). ${ }^{2}$ Temale toetudes (Tuglas 1933, 1935) ${ }^{3}$ tutvustab Mihkel Kampmaa seda lugu lühidalt oma „Eesti kirjanduse peajoontes” (Kampmaa 1936). Palju põhjalikumalt, tuginedes kooliarhiivi dokumentidele ja isiklikele mälestustele, kajastab lugu sündmustes osalenud õpetaja Martin Okas oma ajalehekirjutises (Okas 1925), väljavõtteid sellest publikatsioonist on avaldatud ka Vanemuise seltsi juubelile pühendatud väljaandes (Sööt 1925: 43-46), mida Tuglas on rohkesti kasutanud. Hiljem on uurijad pööranud sellele episoodile suhteliselt vähe tähelepanu, sellepärast söandan seda meelde tuletada, kasutades mõningaid arhiivimaterjale, mis täiendavad teemat huvipakkuvate nüanssidega.

Loomulikult tuleb Tartus 1902.-1903. aastal toimunut käsitleda tsaaririigi venestamispoliitika kontekstis. ${ }^{4}$ Sündmuste kaasaegsed, keda venestamine otseselt mõjutas, kujutasid seda valulist nähtust tihti ainult ohvri positsioonilt, pöörates tähelepanu peamiselt võimude ebaõiglasele tegutsemisele ja sellega seotud repressioonidele. Nimelt nii on kirjutatud Okase ja Karl Eduard Söödi artiklid. Teisiti - analüütiliselt ja kontseptuaalselt - kirjutab meid huvitavatest sündmustest Tuglas, sellepärast olen siinses artiklis lähtunud suures osas tema tekstist.

Tuglase mälestused, nagu üldse head memuaarid, on kirjutatud kahest vaatenurgast: täiskasvanud autori positsioonilt, kes teab, mis tulevikus toimuma hakkab, kuid kes püüab taaselustada teismelise nooruki vaatepunkti teda toona ümbritsenud maailmale. Ta kirjutab XX sajandi alguse Tartust, Üle-

${ }^{1}$ Tuglas on kirjutamisel nähtavasti kasutanud õppeasutuse ajaloole pühendatud töid, nt Kõks 1937; Prazdnovanije 1902 (ta osales 1902. aastal õppeasutuse 25. aastapäeva tähistamisel, viidatud venekeelne brošüür võis tal olla olemas juba kooliajast alates). Eriti rohkesti on ta dokumentaalset ainest leidnud Vanemuise seltsi juubelialbumist (Vanemuine 1925).

${ }^{2}$ Pärast esmatrükki on „Noorusmälestused” eesti keeles ilmunud korduvalt. Kahjuks ei ole teost tõlgitud vene keelde, kuigi see võiks pakkuda huvitavat ainest nii vene kui ka välismaa teadlastele, kes uurivad venestamist ja Vene impeeriumi hariduslugu.

${ }^{3}$ Tuglas kirjutas koolinoorte põrandaalustest rühmitustest Gustav Suitsu 50. sünnipäevale pühendatud artiklis (Tuglas 1933: 1023).

${ }^{4}$ Tsaaririigi venestamispoliitikast Eestis on piisavalt palju kirjutatud, mis vabastab mind vajadusest sellel põhjalikumalt peatuda. Viitan siinkohal järgmistele töödele: Eesti kooli ajalugu 2010: 335 jj; Kasekamp 2011: 112-113; Tartu Ülikooli ajalugu 1982: 263-270; Kisseljova 2017: 36, 108-110 jne. 
jõe linnaosast, kus olid peavarju leidnud kas mitte eriti jõukad või lihtsalt vaesed eestlased ja kus just selle pärast asusid toonased eesti kultuurikeskused: Vanemuise selts, Taara, Karskuse Sõber, Käsitööliste selts. Postimehe talitus asus toona siiski päris linna keskel jõukas linnaosas ja koguni raekoja hoones. Tuglas analüüsib üksikasjalikult ja täpselt tendentse, mis iseloomustasid tolle aja eesti rahvuslikku liikumist. Ta peab õigusega neid aastaid uue rahvusliku ärkamise eelmänguks. See aeg on seotud rahva elatustaseme üldise tõusuga, mis aitas kaasa ka eestlaste eneseteadvuse tõusule. Hakati saama üle tundest, et vastupanu nii sakslaste võimutsemisele kui ka venestamisele on perspektiivitu, aga samuti sellest, et koos ühise asja ajamine pole võimalik. Tuglase mälestused on eriti olulised sellepärast, et kõnelevad toonase päris noore põlvkonna tegemistest, kellest väga kiiresti kujunesid eesti noore haritlaskonna tipptegijad, kes võtsid aktiivselt osa 1905. aasta revolutsioonist ja said hiljem iseseisva Eesti Vabariigi ülesehitajateks.

Eesti-vene kultuuriruumi uurijatele pakuvad nii need mälestused kui ka siin vaadeldavad episoodid huvi selle poolest, kuidas eesti õpilased suhtusid venestamise ajal venekeelsesse kooli, kus nad pidid õppima, kuidas saadi üle bürokraatlikust survest, mis seadis ohtu eesti keele ja kultuuri tuleviku. Tuglase vaade on tähelepanuväärne, sest ta püüab eristada vene kirjandust ja isegi vene haridust (mis kujunes õpilaste jaoks aknaks suurde maailma) poliitilisest tellimusest ja selle elluviijatest - haridusametnikest, kooliinspektoritest ja mõnest pedagoogist (tema õpetajate hulgas polnud kaugeltki kõik innukad venestajad).

Tuglas, tollal veel Friedebert Mihkelson, astus neljaklassilisse Tartu linnakooli 1901. aasta jaanuaris, õppeaasta keskel, ja võeti kohe teise klassi teise jaoskonda. Tuleb silmas pidada, et Vene impeeriumi haridussüsteem oli siis killustatud ja segane, õppeasutuste nimetused ei vastanud alati tegelikkusele - nii kestsid õpingud neljaklassilises koolis hoopis kuus aastat. Tartu linnakoolis õppisid suures enamuses vaeste eesti perekondade järeltulijad (kooli nimetati „talurahva ülikooliks”). Seal oli ka pedagoogiline täiendusklass, mis valmistas ette rahvakoolide õpetajaid ja mille kursus tervikuna vastas õpetajate seminari omale. ${ }^{5}$

Tähelepanuväärne on Tuglase sisseastumine kooli. Ta kirjeldab seda mälestustes teatava iroonia, aga samal ajal ka rahuloluga. Ta ei pidanud tegema eksameid, aga mõned õpetajad esitasid talle küsimusi koolikursuse eri osadest, kõige rohkem huvitas neid vene keele oskus (Tuglas 1940a: 229). Otsustavaks sai Puškini luuletuste peast deklameerimine. „Olin küll maapoiss ja võõras ümbruses, kuid esitades Puškinit ei tundnud ma enam vähematki ujedust" (Tuglas 1940a: 229). Edaspidi tunnistab ta, et vene kirjanduse valdkonnas ületasid tema teadmised klassikaaslaste omi. ${ }^{6}$

Ärme süveneme koolielu üksikasjadesse, mida Tuglas nii värvikalt kirjeldab. Märgime vaid, et vaatamata kriitikale koolikorralduse suhtes kirjeldab ta sümpaatia ja tänutundega paljusid oma õpetajaid (näiteks ajalooõpetajat

\footnotetext{
${ }^{5}$ Õpetajate seminari sai astuda alles pärast riikliku algastme kooli lõpetamist, kuid Tuglas oli lõpetanud ainult kihelkonnakooli.

${ }^{6}$ Tõenäoliselt ei pärinenud need teadmised ainult Prangli kihelkonnakoolist Tartumaal, vaid ka noorukil endal oli juba varakult tekkinud huvi kirjanduse, sealhulgas vene kirjanduse vastu.
} 
Martin Okast (1864-1946), hüüdnimega Votšto, usuõpetuse õpetajat A. Klaasseppa). Eriti tõstab ta esile Aleksandr Mihhailovitš Šušerinit, kes kutsus õpilase oma koju ja andis talle oma koduraamatukogust lugeda vene „pakse” ajakirju, nagu Vestnik Evropõ, Russkoje bogatstvo, Mir Božii, vaidles temaga kirjanduse üle (õpilane kaldus eelistama mässulist Lermontovi, aga õpetaja püüdis teda suunata harmoonilise Puškini poole), innustas õpilase kirjanduslikke katsetusi. Tuglas säilitas sideme õpetajaga ka pärast kooli lõpetamist. ${ }^{7}$ Üldse rõhutab ta, et venelastest õpetajad vaatasid läbi sõrmede emakeele kasutamisele - mis oli kooliseinte vahel keelatud! Seevastu lätlasest pedagoog jälgis teraselt, et õpilased ei räägiks omavahel eesti keeles. ${ }^{8}$ Meelsasti ja pisut humoristlikult meenutab Tuglas koolinäidendeid, mille innustajaks oli õpetaja Pavel Andrejevitš Sirotkin (1866-1938). Gogoli „Naisevõtus” (Tuglase mälestustes „Naitumine”) mängis ta Agafja Tihhonovnat (Tuglas 1940a: 240), juubeliõhtul aga Nastasja Pankratjevna rolli Aleksandr Ostrovski näidendis „Pohmelus võõral peol” (Tuglas 1940a: 241).

Kuid naaskem meid huvitava episoodi - Mihkel Veske mälestusõhtu juurde. Nagu eespool nimetatud, olid sellel patriootilisel algatusel eelkäijad - Lydia Koidula mälestusõhtud. Kuigi nende ametlikeks korraldajateks (nagu selgub arhiivimaterjalidest) olid auväärsed täiskasvanud inimesed, ${ }^{9}$ olid nendegi õhtute tegelikud initsiaatorid ja läbiviijad kooliõpilased - gümnasistid ja reaalkooli õpilased, salaühingu Eesti Külvaja liikmed gümnasist Gustav Suitsu juhtimisel (Tuglas 1940a: 242; Kampmaa 1936: 20). ${ }^{10}$ Need ettevõtmised erutasid Tartu eesti seltskonda ja andsid tõuke järgmise õhtu korraldamiseks, mille organiseerisid linnakooli õpilased. Peaorganisaator Tuglas tunnistab, et õpilased teadsid võrdlemisi vähe Mihkel Veskest, neil oli vaja ajendit oma rah-

${ }^{7}$ Šušerini kohta on säilinud vähe andmeid, ajapikku kaotas Tuglas ta silmist, kuid õpetaja teenistuskirjast (RA, EAA.3847.1.2, 1 47-53) saame teada, et Šušerin on sündinud 1874. aastal Novgorodi kubermangus väikekodaniku perekonnas, lõpetanud SanktPeterburgi õpetajate instituudi 1899. aastal ja määratud õpetajaks Pihkva kubermangu Toropetsi linnakooli, 1900. aastal ümber paigutatud Paide kolmeklassilisse linnakooli. Alates 1901. aastast sai temast esialgu mittekoosseisuline, seejärel aga juba koosseisuline õpetaja Jurjevi linnakoolis. Tõenäoliselt töötas ta vähemalt 1911. aastani Eestis, 1904. aastal abiellus luteri usku Olga Ditsmaniga ja sai temaga mitu last.

${ }^{8}$ „Kui veel venelastest õpetajad õpilaste omavahelise eesti keele rääkimisele läbi sõrmede vaatasid, siis tema [Jānis Davis] juba ei kinkinud" (Tuglas 1940a: 232). Davise kohta (1867-1959) vt: RA, EAA.3847.1.5, samuti vt literatura.lv - Janis Davis. Ta oli populaarsete pedagoogiliste õppevahendite autor ja hiljem karskusliikumise tegelane. Arvatavasti ei olnud ka kõige olulisem venestaja, inspektor Anton Nikonovitš nime järgi otsustades venelane. Ta oli talupoeglikku päritolu, lõpetanud Vilniuse pedagoogilise instituudi nagu ka Davis - samal ajal kui enamik linnakooli pedagooge oli saanud hariduse Sankt-Peterburgi pedagoogilises instituudis (RA, EAA.3847.1.2, 1 79). See oli päris tavaline, et kõige innukamateks venestajateks kujunesid mittevenelased. Et nad polnud rahvuselt venelased, sundis see neid nähtavasti tundma end ebakindlalt ja just sellepärast eriti innukalt täitma juhtkonna korraldusi. Nende hulka kuulus ka, nagu me edaspidi näeme, Riia õpperingkonna ülem, poolakas Czeslav Zajonczkowski.

${ }^{9}$ Üht nimekirja varianti vt Issakov 1968: 622-623. Teise dokumendi järgi olid „õhtu korraldajateks „Taara” seltsis õpetaja Kima, Johann Leppa, Paul Kurvits ja Friedrich Karlson, aga seltsis „Karskuse sõber” tsensor Jõgeveri naine, rahukogu kirjutaja Kase naine ja doktor Schulzenbergi naine" (RA, EAA.325.1.490, l 143-144, säilitatud on venekeelse teksti nimekujud).

${ }^{10}$ On tähelepanuväärne, et Gustav Suitsu nime ei ole politseipristavi raportis üldse mainitud, nagu ka Friedebert Mihkelsoni nime (Issakov 1968: 621-623). 
vuslike tunnete väljendamiseks. Nad soovisid haarata oma ettevõtmisega nii kogu kooli kui ka linnaelanikke, ja ta tõdeb lõpuks üllatusega, et see neil ka õnnestus (Tuglas 1940a: 243).

Õppeasutuse lõpuklass, kus Tuglas õppis, osales mälestusõhtul peaaegu täies koosseisus. Ühe klassikaaslase kaudu õnnestus saada esinema Jaan Tõnisson, kes kõneles Mihkel Veskest kui keeleuurijast, luuletajast ja avaliku elu tegelasest, etnograaf ja ajaloolane Aleksander Põrk rääkis muistsetest uskumustest (tema teemaks oli Tõnnile ohverdamine ja tõnnivakk), Karl August Hermann meenutas Vesket kui oma eelkäijat eesti keele lektori ametikohal Tartu ülikoolis, õpetaja Martin Okas analüüsis Veske luuletust „Isa sõnad", kuid tema ettekande esitas Vanemuise seltsi esimehe asetäitja, tuntud pedagoog Mart Reinik. Tuglas kandis ette oma „oodi” Mihkel Veske auks, esitati lühinäidend ja õhtu lõppes tantsuga õpilasorkestri saatel, mida juhatas õpetaja D. Alba.

Tuglas rõhutab, et õpilased ei lubanud endale õhtul mitte midagi, mis oleks väljunud lubatu raamidest (Tuglas 1940a: 244). Siiski peitus tema organiseerimistöös varjatud kavalus: õhtu toimus perekondliku peona (nagu ka Koidula mälestuse tähistamine), mille organiseerimiseks ei olnud vaja küsida eriluba, samuti polnud vaja esitada politseile programmi; kas sellel või mõnel muul põhjusel ajalehed isegi ei kirjutanud ei Veske ega Koidula õhtutest. Kuid kavalus ei aidanud ja tagajärjed ei lasknud kaua oodata. Võimude ees kannuseid teenida sooviva tähelepaneliku silma eest ei jäänud varjule sisemised impulsid, mis juhtisid õpilaste tegevust. Tuglas sõnastas selle järgmiselt: „Miks pidime ainult vene suurmehi mälestama ja kroonukeeles pidusid korraldama? Meie ise olime ka olemas!" (Tuglas 1940a: 243) Lisagem omalt poolt, et kõik toimus linnas, mida autor on iseloomustanud järgmiselt: „Vene võõbaga saksa linn eestlaste maal!” (Tuglas 1940a: 235), kus „saksu vihati ja venestus oli vastukarva nähtus" (Tuglas 1940a: 226). Teiste sõnadega: õpilased organiseerisid rahvusliku ja patriootilise ürituse, mis vastandus venestamisideele.

Kuu aega pärast üritust hakkas olukord linnakoolis muutuma pingeliseks. Okas on oma kirjutises üksikasjalikult taastanud sündmuste käigu. Uurimise initsiaatoriks sai inspektor Anton Nikonovitš, kes näitas üles erakordset usinust informatsiooni kogumisel. Ta sõitis ise Riiga, kaasas kaebus õpperingkonna juhtkonnale (Okas 1925; Sööt 1925: 44). Võimalik, et just tema andis informatsiooni ka politseiülemale. Asjaolude uurimiseks saabus kohale kõrge komisjon, millesse kuulusid õpperingkonna ülem Czeslav Zajonczkowski, Liivimaa rahvakoolide direktor Anatoli Vilev, Jurjevi kreisi rahvakoolide inspektor Nikolai Beldjugin ja loomulikult ka linnakooli inspektor Nikonovitš. Veske mälestusõhtu osalisi oli liiga palju - 76 õpilast (st rohkem kui veerand õpilaskonnast, sealhulgas 27 lõpuklassist) ja neli pedagoogi. ${ }^{11}$ On arusaadav, et neid kõiki polnud võimalik rangelt karistada, mõnel õpilasel alandati käitumishinnet, aga Tuglas hindas olukorda ja lahkus koolist tervislikel põhjustel. Teistest rohkem said kannatada õpetajad Mihhail Lukin, kes vallandati, ja

11 Tuglase lemmikõpetaja Šušerin ei osalenud õhtul, erinevalt Sirotkinist ei olnud ta pärit Eestist ega osanud eesti keelt. 
Martin Okas, ${ }^{12}$ kes viidi Tartust üle Kuramaa kubermangu; Sirotkinile määrati noomitus. Alba jäi karistuseta, kuigi oli sunnitud kirjutama seletuskirja (riskeerin oletada, et Nikonovitš ei soovinud jääda ilma õpilasorkestrist, mille üle ta uhkust tundis). Kuid Veske õhtu uurimine tõstis pinnale ka Koidula mälestusõhtu korraldajad. Gustav Suits visati ajutiselt gümnaasiumist välja (mis iseenesest kõneleb sellest, et politseiülema kaebus ei olnud uurimises ainus oluline dokument). Muide, see ei olnud takistuseks sellele, et ta 1904. aastal lõpetas hiilgavalt gümnaasiumi ja sai kuldmedali. Tuleb tõdeda, et isegi kõige süngemal venestamisajal ei olnud tsaarivalitsus liiga verejanuline: Tuglas lõpetas selsamal 1903. aastal linnakooli eksternina ja Sirotkin sai pärast Nikonovitši surma 1907. aastal tema õpetaja-inspektori ametikoha.

Siiski ärgem vähendagem ka negatiivseid tagajärgi. Politsei hakkas rohkem tegelema Vanemuise seltsiga: tehti takistusi ürituste korraldamisel, seltsi juhid ja seltsiga seotud inimesed pidid leppima politsei järelevaataja alandavate visiitidega, nad olid sunnitud andma tunnistusi ja kirjutama mitmesuguseid seletuskirju. Näiteks 4. märtsil 1903 andis selts sisse taotluse korraldada 17. augustil 1903 Jaama tänava aias meelelahutusliku programmiga rahvapidu: teatrietendus, muusika, laul, pantomiim, elavad pildid, illuminatsioon, tulevärk, tants, võimlemine. Esialgu, 5. märtsil, sai taotlus positiivse resolutsiooni: „Peo korraldamiseks pole takistusi. Mis puutub kõnesse, siis kõne tekst tuleb kinnitada vastavalt kehtivale korrale, aga mis puudutab teatriettekandeid, siis tuleb esitada näidendid draamakunsti tsensori allkirjaga." Kuid hiljem on see resolutsioon maha tõmmatud ja kirjutatud uus (ilmselt pärast seda, kui oli alustatud uurimist mälestusõhtute asjus): „Kuna ühingu põhikirjas ei ole ette nähtud rahvapidude korraldamist, siis selle taotlusega peab selts pöörduma kuberneri poole" (RA, EAA.325.1.490, 1 38-38p). Kuberner hakkas umbusaldama Vanemuise seltsi, mis oli teinud vea Veske õhtu korraldamisega, ja andis taotlusele keelduva vastuse (RA, EAA.325.1.490, 1 42), kusjuures kordustaotluse lükkas ta tagasi juba teatava ärritusega: „Teen Teie Kõrgeaususele ettepaneku," kirjutab ta Jurjevi politseiülemale 23. mail 1903, „teatada Vanemuise seltsi vanemate nõukogule mulle saadetud taotluse asjus, et mitte nõustudes mulle esitatud seltsi ettepanekutega, ei saa ma muuta oma korraldust Teile saadetud ettepaneku kohta 29. märtsist k. a, nr 2894" (RA, EAA.325.1.490, 1 40). Igale sellisele korraldusele järgneb toimikus pikk rida kviteeringutest, mille on andnud taotlusega tegelenud isikud selle kohta, et nad on korraldust lugenud või sellega tutvunud (RA, EAA.325.1.490, 140 jne).

Ja siiski ei olnud ei Tartu politseil ega kubermanguvõimudel ilmselt tõsisemat huvi selle vastu, et kurikuulsal kirjandusõhtute lool oleksid veel kaugemale ulatuvad tagajärjed kohalikele kultuuriühingutele. Politsei tegevus oli varjamatult hoopis mõistlikum kui pedagoogidest bürokraatide algatused. Seda tunnistas isegi Okas, kes muidu kaldus kasutama pigem tumedamaid toone. Seoses sellega kirjutas kuberner, kindralleitnant Mihhail Aleksejevitš

${ }^{12}$ Martin Ivanovitš Okas (nagu teda nimetatakse teenistuskirjas, RA, EAA.325.1490, 1 8-10) sündis 1864. aastal, lõpetas 1892. aastal Sankt-Peterburgi õpetajate instituudi, töötas õpetajana Võrus ja Pärnus, 1898. aastal asus tööle Jurjevi linnakoolis. 29. juulil 1903 paigutati ta Riia õpperingkonna korraldusega nr 6242 ümber Talsi linnakooli. Hiljem naasis Eestisse, aastatel 1919-1933 töötas sellesama kooli direktorina, kust ta kunagi vallandati siis kandis see nime Tartu 15. Algkool. Tema portree on leitav teosest Algkool 1937: 3. 

(1858-1909) 21. aprillil 1903:

Vastates Teie raportile 18. märtsist nr 92, teen Teie kõrgeaususele ettepaneku selgitada seltside Karskuse Sõber ja Taara ruumides eelmise aasta 11. detsembril toimunud kirjandusõhtute korraldajatele, et ainult sellel korral, arvestades seda, et sündmus toimus ammu, jätan korraldajate poolt nende õhtute seaduslike formaalsuste täitmata jätmise tagajärgedeta, kuid selliste kõrvalekaldumiste kordumisel seaduslikest ja Riiklikest korraldustest selles käsundusvaldkonnas allutatakse süüdlased vastavalt minu rahvakogunemisi puudutavatele kohustuslikele määrustele, karistamisele administratiivkorras. (RA, EAA.325.1.490, 1 54, kiri nr 523)

Selsamal päeval katkestati kuberneri kirjaga Mihkel Veske kirjandusõhtu süüasi „ilma tagajärgedeta” (RA, EAA.325.1.490, 1 56, kiri nr 533), kuigi Paškov kirjutas seal, et õigustuste alusetus on talle ilmselge:

Pean vajalikuks lisada sellele, et kuigi Vanemuise seltsi juhatuse selgituses räägitakse, nagu oleks kesk- ja algastme õppeasutuste osavõtt 17. jaanuari õhtust olnud juhuslik, lükkab selle avalduse siiski täielikult ümber toimikus leiduv, õhtu korraldajate, linnakooli õpilaste nimel, saadetud kutse-pilet. (RA, EAA.325.1.490, 1 56-56p)

Loomulikult järgnes ka hoiatus: „edaspidi mitte lubada seltsi korraldatud õhtutele kesk- ja alamate koolide õpilasi ilma nendepoolse eelneva loa taotluseta vastavate õppeasutuste Juhtkonnalt” (RA, EAA.325.1.490, 1 56p).

Seega otsustas kuberner lõpuks mitte kasutada repressioone. Enne seda lugu ei olnud ta eriti informeeritud Vanemuise seltsist - millest andis tunnistust esimeses dokumendis avaldatud nõudmine kanda talle ette ,selle seltsi koosseisust (liikmete arv, juhtide nimed) ja selle tegevusest (millised institutsioonid millega tegelevad?)" (RA, EAA.325.1.490, 1 54) -, ja nõudis 8. märtsil 1903. aastal kiireid selgitusi („viivitamatult nõuda Vanemuise seltsi vanemate kogult mulle esitamiseks otseseid selgitusi, millisel alusel korraldati nende poolt 17. jaanuaril k. a kirjandusõhtu ilma selle korraldamiseks vajaliku loata”) (RA, EAA.325.1.490, 1 54). Tõenäoliselt jahendas kõrgema kubernerivõimu selline suhtumine ka Tartu agarate venestajate innukust.

Kõige toredam on see, et kurikuulus augustipidu toimus lõpuks 24. augustil 1903 ja luba selle pidamiseks saadi Peterburist, siseministeeriumist (Sööt 1925: 48). See tundub erinevate võimustruktuuride tavalise vene moodi koordineerimatusena ja võitlusena mõjusfääride pärast, aga näitab ka kohalike juristide kõrget kvalifikatsiooni. Nad oskasid kirjutada õige taotluse ja leida võimurite seisukohalt õigeid argumente.

Niisiis, Tartu kooliõpilaste vastasseis impeeriumi venestamispoliitikale, mis väljendus „ebaseaduslike” eesti kirjanduslike õhtute korraldamises oma rahvuskultuuri tegelaste mälestuseks, lõppes suhteliselt rahulikult. Noored võitlejad said edukalt kooli lõpetada. Nagu tunnistab Suitsu ja Tuglase edasine tegevus, oskasid nad eristada impeeriumi poliitikat ja vene keelt, mida kasutati väikerahvaste rahvustunde allasurumiseks. Niisugune poliitika pidi para- 
tamatult kutsuma esile vastutegevuse ja aitas ainult kaasa rõhumise alt vabanemise püüdele. Jan Baudouin de Courtenayl oli õigus, kui ta ennustas 1913. aastal venestamise teele asunud Vene impeeriumi lõppu (Baudouin de Courtenay 1913). Ja veel kord tuleb mõtelda selle üle, kui palju kurja võib kaasa tuua isegi kõige tühisema ametniku püüdlus teenida ülemuste ees kannuseid ja liikuda teenistusredelil edasi, nuhkides ning kaevates oma kolleegide ning õpilaste peale. Samuti tuleb mõtelda sellele, et isegi politseiametnike hulgas oli mõistlikke inimesi (Zabelin s.a).

Kuid nendel noorte aktsioonidel oli veel üks oluline tagajärg. Nagu tuleb välja Issakovi publikatsioonist, levitati 4. aprillil 1903. aastal Tartus hektograafil paljundatud venekeelset lendlehte, mis algas pöördumisega „Seltsimehed eestlased" (Issakov 1968: 623). Selles on samuti kokku võetud kooliõpilaste tagakiusamise lugu kirjandusõhtute korraldamise pärast ja süüdistatud selles kohalikke pedagooge:

Hiljuti leidis meie linnas aset kuulmatu lugu: kooliülemuste terav kõrv oli tabanud teate vaba iseloomuga koosviibimiste kohta, mis toimusid kohalikes eesti seltsides; neil koosviibimistel oli ka õppivat noorsugu. Ja seal sõidab siinsete pedagoogide aruande peale Riiast kohale ringkonna inspektor, kes koos nendesamade hariduse eestvõitlejatega hakkab korraldama õpilaste juures läbiotsimisi nagu ehtne sandarm kunagi. (vt tsitaati lendlehest Issakov 1968: 623)

Edasi läksid lendlehe tundmatud autorid üle juba poliitilistele süüdistustele isevalitsuse suhtes, kutsudes rõhutud rahvaid üles solidaarsusele ja ühisele võitlusele režiimiga:

Kõik teavad, kui suurte raskustega on meil seotud koolide avamine, kuidas kiusatakse taga rahvakooliõpetajaid, kes julgevad õpetada rahvast üle selle programmi, mida pimedusekummardajad on ette kirjutanud. Et juhtida õigustatud rahulolematust tema vastu rahvusliku vaenu sihis, ässitab isevalitsus üht rahvust teise kallale. Vaatamata oma valelikele sallivuselubadustele katsub ta maha suruda muulaste vähimatki rahvusliku iseteadvuse vaimu [---] ta venestab Poolat ja Baltimaid, kiusab taga lahkusulisi ja kõiki, kes valitsevasse usku ei kuulu, - ja see kõik sünniks nagu vene rahva ja õigeusu huvide pärast. Kõik vabad ja murdmatud jõud peavad üles tõusma isevalitsuse omavoli vastu, me kõik peame liituma ühiseks võitluseks ja iga rahva lähimaks ülesandeks peab olema isevalitsuse kukutamine: üksnes omavoli langemine annab avara võimaluse rahvuslike jõudude omanäoliseks arenemiseks. Liitugem siis, vennad, et võidelda üheskoos. (vt tsitaati lendlehest Issakov 1968: 623)

Lendlehele oli alla kirjutatud: „Tartu ühendatud üliõpilasseltside ja organisatsioonide liidu nõukogu". Tõele au andes oli selles muljet avaldavas dokumendis otse välja öeldud see, mida mõtlesid paljud mälestusõhtutel osalenud, kuigi on võimalik, et nad ei formuleerinud oma mõtteid veel nii teravalt.

Aga uue perioodi alguseni oli jäänud vähem kui kaks aastat. Osalemise eest 1905. aasta revolutsiooni sündmustes pandi 19-aastane Tuglas vangi ja hiljem siirdus ta maapakku. Noor-Eesti liikumise algataja Gustav Suits sõitis 
1905. aastal õppima Soome ja hiljem sai temast üks Eesti sotsialistide-revolutsionääride partei liidreid. Tartu koolipoiste venestamisvastane protest sai tähelepanuväärse järje.

\section{Venekeelsest käsikirjast tõlkinud MALL JÕGI}

Artikkel on kirjutatud projekti IUT34-30 („Tõlkeideoloogia ja ideoloogia tõlkimine: kultuuridünaamika mehhanismid Eestis vene ja nõukogude võimu tingimustes 19.-20. sajandil”) raames.

\section{Arhiivimaterjalid}

RA - Rahvusarhiiv

EAA.325. - Tartu linna politseivalitsus

EAA.3847.1 - Tartu kõrgem algkool

\section{Internetiallikad}

Zabelin, Nikandr s. $a$. = Zabelin Nikandr Mihajlovič. Russkaja Èstonija. (Забeлин Никандр Михайлович, Русская Эстония.) - http://russianestonia.eu/index. php?title=Забелин_Никандр_Михайлович (26. VII 2019).

literatura.lv - Janis Davis. http://literatura.lv/lv/person/x?PersonSearch\%5Bname $\% 5 \mathrm{D}=$ janis+davis\&PersonSearch\%5BbirthDate\%5D (5. IX 2019).

\section{Kirjandus}

Algkool 1937 = Tartu Linna XV Algkool: 1837-1937. Tartu.

Baudouin de Courtenay 1913 = Baudouin de Courtenay, I. A. Nacional'nyj i territorial'nyj priznak v avtonomii. Sankt-Peterburg. (Бодуэн де Куртенэ И. А. Национальный и территориальный признак в автономии. Санкт-Петербург.)

Eesti kooli ajalugu 2010 = Aleksander Elango, Endel Laul, Allan Liim, Väino Sirk, Eesti kooli ajalugu. Kd 2. Tallinn: Teaduste Akadeemia kirjastus.

Is s akov, Sergei 1968. Arhiivipudemeid. L. Koidula ja M. Veske mälestusõhtud Tartus 1902. ja 1903. a. - Keel ja Kirjandus, nr 10, lk 621-624.

Ka m p m a a, Mihkel 1936. Eesti kirjandusloo peajooned. Neljas jagu. Tartu: Eesti Kirjanduse Seltsi kirjastus.

Ka s ek a m p, Andres 2011. Balti riikide ajalugu. Tlk Marek Laane. Tallinn: Varrak.

Kisseljova, Ljubov 2017. Eesti-vene kultuuriruum. Tartu: Tartu Ülikooli Kirjastus.

Kõks, Jaan 1937. Pilk Tartu Linna XV Algkooli minevikku. - Tartu Linna XV Algkool: 1837-1937. Tartu.

Okas, Martin 1925. Dr. M. Veske sünnipäevapeo tagajärjed 1903. aastal. - Postimees 11 . V, nr 126; 12. V, nr 127. 
Prazdnovanie 1902 = Prazdnovanie dvadcatipjatiletnego jubileja Jur'evskogo četyrehklassnogo gorodskogo učilišča: 1877-1902. Jurjev. (Празднование двадцатипятилетнего юбилея Юрьевского четырехклассного городского училища: 1877-1902. Юрьев.)

Sö öt, Karl Eduard 1925. „Vanemuise” Seltsi majandusline olukord ja Seltsi juhatuse korraldatav tegevus. - Vanemuine 1865-1925. Tartu: Vanemuise kirjastus.

Tartu Ülikooli ajalugu 1982. Kd 2: 1798-1918. Koost Helmut Piirimäe, toim Karl Siilivask. Tallinn: Eesti Raamat.

Tuglas, Friedebert 1933. Noor-Eesti algajult. Gustav Suitsu 50-nenda sünnipäeva puhul. - Looming, nr 9, lk 1019-1025.

Tuglas, Friedebert 1935. Gustav Suits Noor-Eesti algajul. - F. Tuglas, Kriitika II. Tartu: Noor-Eesti.

Tuglas, Friedebert 1940a. Tartu linnakoolis. Memuaare. - Looming, nr 3, lk $226-247$.

Tugl a s, Friedebert 1940b. Noorusmälestused. Tartu: Ilukirjandus ja Kunst. Vanemuine 1925 = Vanemuine 1865-1925. Tartu: Vanemuise kirjastus.

Ljubov Kisseljova (snd 1950), Tartu Ülikooli vene kirjanduse professor (Ülikooli 18, 50090 Tartu), slavistika osakonna juhataja, ljubov.kisseljova@ut.ee

\section{Schoolboy acts of resistance to the policy of Russification in Tartu in the early 1900s}

Keywords: policy of Russification in the Russian Empire, repressions and resistance, public city school of Tartu, memorial evenings for Koidula and Veske, Friedebert Tuglas, Gustav Suits

The article describes some remarkable events that took place in Tartu in 1902 and 1903, when young students under the leadership of Gustav Suits and Friedebert Tuglas assisted by the local Estonian societies Vanemuine, Taara, and Karskuse sõber /Friend of Abstinence/ organised special literary evenings to celebrate the memory of Lydia Koidula and Mihkel Veske, the great figures of the Estonian people. This was a protest of youth against the policy of Russification, an action marking the beginning of a new phase of Estonian national movement. Using various sources, including some new material discovered in the archives, the article reconstructs the stories of how those evenings were prepared and what repressions followed. It is revealed that the information was leaked by the city school inspector, who was eager to win his spurs and move on careerwise. The authorities, however, were reluctant to make a big deal out of the incident and so the affair ended relatively peacefully. The young rebels were able to graduate with success, while the above incident turned out to be a prologue to their further fight for a free Estonia.

Ljubov Kisseljova (b. 1950), PhD, University of Tartu, Ordinary Professor of Russian Literature (Ülikooli 18, 50090 Tartu), Head of the Department of Slavic Studies, ljubov.kisseljova@ut.ee 